\title{
Tingkat keberhasilan reklamasi lahan bekas tambang batubara pada PT Bukit Baiduri Energi Kabupaten Kutai Kartanegara kota Samarinda Kalimantan Timur
}

\author{
Marlon Ivanhoe Aipassa ${ }^{1^{*}}$, Harjuni Hasan ${ }^{2}$, Zainuddin ${ }^{3}$ \\ ${ }^{1}$ Program Pascasarjana Magister Ilmu Lingkungan Universitas Mulawarman, Samarinda, Indonesia \\ ${ }^{2}$ Teknik Pertambangan Universitas Mulawarman, Samarinda, Indonesia \\ ${ }^{3}$ Dinas Lingkungan Hidup Kabupaten Kutai Timur, Kalimantan Timur, Indonesia \\ Koresponden E-mail: marlon.ivanhoe@gmail.com
}

(Diterima 02 Maret 2020|Disetujui 14 Juni 2020|Diterbitkan 30 Juli 2020)

\begin{abstract}
Kartanegara Regency and Samarinda City East Kalimantan. From the results of the research and evaluation of the reclamation plan documents and RKTTL, as well as the reclamation implementation report, the Backfilling plan for 2017 is $35.80 \mathrm{Ha}$ and is realized at $22.36 \mathrm{Ha}$, so that the percentage of success rates reaches $62,46 \%$. The land management and land revegetation plan for 2017 is $62.12 \mathrm{Ha}$ and is realized at $10.26 \mathrm{Ha}$, so that the percentage of success rate is 16.52\%. Revegetation of PT BBE land for the last 3 (three) years from 2015-2017 with a plan of 165.17 $\mathrm{Ha}$ and realized as much as $129.05 \mathrm{Ha}$, resulting in a percentage of success rate of $78.13 \%$, but when compared with the total realization of reclamation (land arrangement) amounting to $109.06 \mathrm{Ha}$, realization of revegetation $129.05 \mathrm{Ha}$, then the success rate of revegetation of reclaimed land is $118.33 \%$. This shows that PT BBE's commitment to environmental management is quite good. Based on the results of laboratory analysis, water quality at all outlet points of PT BBE compliance still meets environmental quality standards of $p H$ 6-7 (BML 6-9). While the soil quality of top soil does not meet environmental quality standards (soil $p H 3.68$ ). Based on the overall evaluation results, the percentage of successful reclamation implementation at PT BBE is $78.43 \%$ (categorized as moderate).
\end{abstract}

\section{Keywords: Ex-mining land, Evaluation, Criteria and level of success}

Batubara yang berkadar sulfur tinggi, dapat menghasilkan jumlah sulfat (SO42) dan klorida (Cl-) yang berlebihan dalam drainase tambang yang berdampak negatif terhadap kualitas air permukaan dan air tanah (Paul T. Behum, et al, 2018). Penambangan batubara sering menyebabkan degradasi lahan yang serius, erosi tanah, dan desertifikasi yang mempengaruhi pertumbuhan vegetasi lokal (Yinli Bi, et al, 2018), karena penambangan mengubah lanskap alam dan mengeluarkan limbah dalam jumlah besar yang menimbulkan bahaya pencemaran serius bagi lingkungan, kesehatan manusia, dan agribudaya (Emma Sandell Festin, et. all, 2018). Penggalian sumber daya batubara, banyak lahan rusak dan masalah lingkungan yang serius terjadi. Dengan demikian, reklamasi lahan tambang batubara telah menjadi tugas penting untuk mencapai target penambangan hijau (Zhenqi Hu, 2018). Faktor sosial juga merupakan faktor utama yang mempengaruhi perubahan tutupan vegetasi yaitu populasi, ekonomi, konduksi struktur industri pemerintah dan sebagainya (Zhang, et al, 2018).

Penggunaan lahan pascatambang yang cocok dan efektif yang berkelanjutan untuk generasi mendatang sangat penting bagi keberhasilan dan keuntungan jangka panjang bisnis pertambangan dan bagi manfaat ekonomi pemilik lahan di masa depan (Jeff Skousen \& Carl E. Zipper, 2014). Namun dampak negatif kegiatan tambang tersebut mengakibatkan kualitas lingkungan menurun. Oleh sebab itu penggunaan program revegetasi yang sesuai, yang membutuhkan pemilihan jenis tanaman yang tepat untuk digunakan dan karakteristik lokasi, dapat meningkatkan stabilitas jangka panjang, baik secara mekanis dan ekologis (Ranjan et al, 2015). Perencanaan pasca tambang yang tepat untuk diterapkan adalah reklamasi lahan tambang. Menurut definisi, "reklamasi" akan mengembalikan lahan ke kondisi yang sama dengan atau lebih besar dari penggunaan sebelumnya tertinggi. Tanah tersebut, setelah reklamasi, harus sesuai untuk penggunaan sebelumnya atau harus memiliki penggunaan yang lebih ekonomis. atau nilai sosial dari penggunaan sebelumnya (Wyoming State Rules \& Regulations 2017).

PT Bukit Baiduri Energi merupakan perusahaan pertambangan batubara yang area konsesinya berada di Kabupaten Kutai Kartanegara dan Kota Samarinda Provinsi Kalimantan Timur pada IUP KW 96PO0160 $(3.081 \mathrm{Ha})$ dan IUP KW 96PP0430 (1000 Ha). Sebagian besar tambang batubara berlokasi di daerah yang rentan secara ekologis, kerusakan ekologis bahkan mungkin lebih serius. Oleh karena itu, masalah khusus ini fokus pada reklamasi lahan di kawasan yang rentan secara ekologis (Zhenqi $\mathrm{Hu}, 2018$ ). Semakin luasnya area bekas tambang PT. Bukit Baiduri Energi yang tidak direklamasi, sehingga menjadi kolam atau disebut "void" (Permen ESDM RI No. 1827 K/30/MEM/2018) dan apabila tidak dilakukan pengelolaan, mengakibatkan kualitas lingkungan menurun dan tidak memenuhi baku mutu lingkungan (UU No. 32 Tahun 2009).

Berdasarkan hal tersebut diatas, maka dianggap perlu untuk dilakukan evaluasi pelaksanaan reklamasi 
PT. Bukit Baiduri Energi berdasarkan dokumen Rencana Reklamasi, Rencana Kerja Tahunan Teknis dan Lingkungan (RKTTL) dan, Rencana Reklamasi (RR) yang bertujuan untuk mengkaji proses pelaksanaan reklamasi lahan bekas tambang dan memberikan penilaian (presentasi) keberhasilan reklamasi.

\section{BAHAN DAN METODE}

Penelitian ini dilaksanakan pada bulan AprilJuni 2018 di area pascatambang PT. Bukit Baiduri Energi baik di wilayah Kabupaten Kutai Kartanegera maupun Kota Samarinda, Kalimantan Timur pada koordinat 0o 20' 38,4" - 0o 34' 30,1" LS dan 117o 08' $34,4 "$ - 117 o 02 ' 35,9" BT.
Evaluasi keberhasilan reklamasi pasca tambang meliputi: (a) penatagunaan lahan, dengan objek kegiatan: penataan permukaan tanah, backfilling (Rum Jungle, 2016), penebaran tanah pucuk, pengendalian erosi dan pengelolaan air, (b) revegetasi meliputi: penanaman (rasio tumbuh $>80 \%$ ) dan pengelolaan air asam tambang (c) penyelesaian akhir dengan objek kegiatan: penutupan tajuk $(>80 \%)$, pemeliharaan, pemenuhan standar reklamasi (Permen ESDM No. 07 Tahun 2014). Untuk memenuhi beberapa persyaratan tersebut, dilakukan evaluasi dokumen (a) Rencana Kerja Tahunan Teknis dan Lingkungan, (b) Rencana Reklamasi serta melakukan wawancara (Silverman, D. 2015) kepada Health Safety and Environtment (HSE) dengan materi "pencapaian target pelaksanaan reklamasi dan revegetasi".

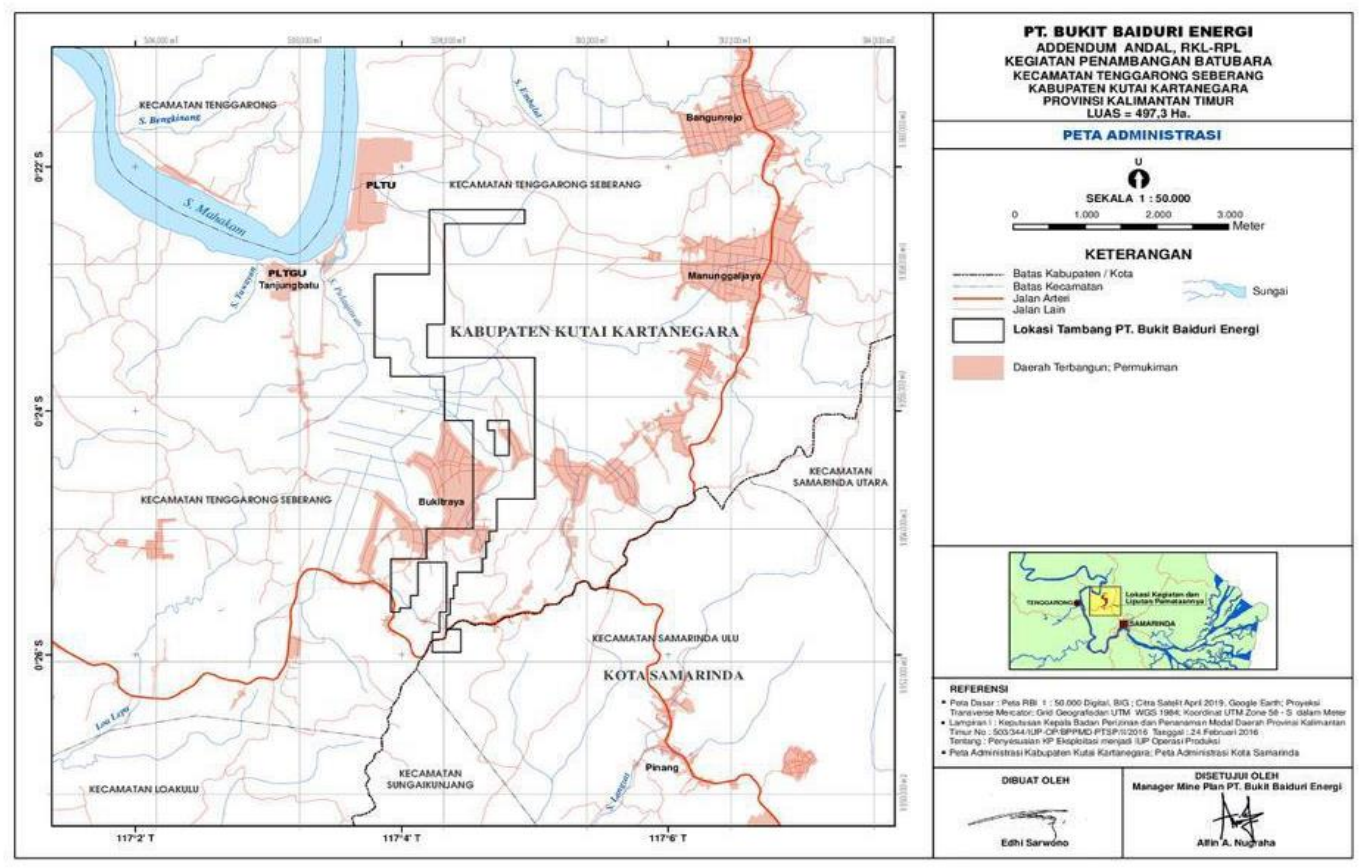

Gambar 1. Lokasi Penelitian

Penggunaan software ArcMap Vers 10.5 (https://www.esri.com) untuk menganalisis (a) luas lahan terganggu, (b) luas lahan reklamasi dan revegetasi, (c) jumlah, luas dan jenis tanaman pioner telah ditanam, dan (d) jumlah, jenis tanaman sisipan,

Presentasi tingkat keberhasilan reklamasi dan revegetasi dihitung dengan menggunakan rumus (Permen ESDM No.1827 K/30/MEM/ 2018 Tahun 2018), sebagai berikut :

$$
\mathrm{TN}=\sum^{n} \frac{T S}{S M(n \times 3)} \times 100 \%
$$

Dimana : $T N=$ Total Nilai Evaluasi, $T S=$ Total Skor Evaluasi, $S M=$ Nilai maksimal,$n=$ Jumlah kriteria

\section{HASIL}

Berdasarkan Rencana Kerja Tahuna Teknis dan Lingkungan, bahwa rencana produksi batubara PT. Bukit Baiduri Energi tahun 2015-2017 (tabel 1).

Tabel 1. Rencana dan Realisasi Produksi tahun 2015-2017

\begin{tabular}{|c|c|c|c|c|c|c|}
\hline \multirow[t]{2}{*}{ Tahun } & \multicolumn{3}{|c|}{ Rencana } & \multicolumn{3}{|c|}{ Realisasi } \\
\hline & $\begin{array}{l}\text { Caol } \\
\text { (MT) }\end{array}$ & $\begin{array}{c}\mathrm{OB} \\
(\mathrm{BCM})\end{array}$ & $\overline{S R}$ & $\begin{array}{l}\text { Caol } \\
\text { (MT) }\end{array}$ & $\begin{array}{c}\mathrm{OB} \\
(\mathrm{BCM})\end{array}$ & SR \\
\hline 2015 & 1.941 .111 & 22.366 .899 & 11,52 & 598.950 & 6.660 .236 & 11,12 \\
\hline 2016 & 321.759 & 1.929 .842 & 6,00 & 31.662 & - & \\
\hline 2017 & 1.018 .572 & 17.826 .662 & 17,50 & 431.553 & 6.364 .709 & 14,75 \\
\hline
\end{tabular}




\section{Reklamasi}

Pelaksanaan reklamasi berdasarkan Rencana Kerja Tahunan Teknis dan Lingkungan dan Rencana Reklamasi, meliputi: (a) penimbunan kembali bekas tambang atau "backfilling" (Rum Jungle, 20126) (b) penataan lahan, dan (c) penebaran top soil. Berdasarkan evaluasi diperoleh hasil luas lahan reklamasi tahun 2015-2017 (tabel 2)

Tabel 2. Luas Lahan Reklamasi 2015 - 2017

\begin{tabular}{cllcccc}
\hline No & Lahan & & 2015 & 2016 & 2017 & Total \\
\hline 1 & Bukaan Lahan & Rencana (Ha) & 59.73 & 40,54 & 68,23 & 168,50 \\
& & Realisasi (Ha) & 68.23 & 0 & 1,99 & 70,22 \\
\multirow{2}{*}{2} & \multirow{3}{*}{ Lahan kegiatan } & Persentase (\%) & 114.23 & 0 & 2,92 & 41,67 \\
& Tambang & Rencana (Ha) & 115.71 & 40.54 & 65.92 & 222,17 \\
& & Realisasi (Ha) & 14.39 & 0 & 1.99 & 16,38 \\
3 & \multirow{2}{*}{ Disposal (Bacfilling) } & Persentase (\%) & 12.44 & 0 & 3.02 & 7,37 \\
& & Rencana (Ha) & 83.24 & 6.27 & 35,80 & 89,51 \\
& & Realisasi (Ha) & 26.11 & 0 & 22,36 & 48,47 \\
4 & \multirow{2}{*}{ Penataan Lahan } & Persentase (\%) & 31.37 & 0 & 62.46 & 54,15 \\
& & Rencana (Ha) & 92.40 & 42.72 & 62.12 & 197,24 \\
& & Realisasi (Ha) & 73.88 & 24.92 & 10.26 & 109,06 \\
\end{tabular}

Sumber: Dokumen RKTTL

Tabel 3. Backfilling 2015 - 2017

\begin{tabular}{clccc}
\hline Tahun & Lokasi & $\begin{array}{c}\text { Rencana } \\
(\mathrm{Ha})\end{array}$ & $\begin{array}{c}\text { Realisasi } \\
(\mathrm{Ha})\end{array}$ & $\begin{array}{c}\text { Persentasi } \\
(\%)\end{array}$ \\
\hline \multirow{2}{*}{2015} & Merandai CD2 & 11,21 & 0 & 0 \\
& Merandai CD1 & 0,62 & 0 & 0 \\
& Pit 6 & 28,91 & 2,30 & 8 \\
& Bendang A4-BX & 8,83 & 5,05 & 57 \\
& Panorama Utara & 0,29 & 0,57 & 197 \\
& Pinang ph 2-3 A6-A8 & 5,59 & 4,70 & 84 \\
& Satelite & 1,18 & 0 & 0 \\
& Central P,S,T & 7,99 & 0 & 72 \\
& North Ph 2-3 A11-A16 & 11,48 & 78 \\
& North Ph 4-5 & 16,04 & 2,01 & 31 \\
& Bendang (A4-BX) & 2,58 & 0 & 0 \\
\end{tabular}

Sumber: Dokumen RKTTL

\section{Penebaran top soil}

Hasil evaluasi rencana reklamasi, menyebutkan bahwa penebaran top soil pada tahun 2015-2017 terdapat 4 lokasi yang menjadi prioritas, dengan ketebalan antara 20-35 cm (Lucia Febriarlita, 2017) (tabel 4).

Tabel 4. Penebaran Top Soil

\begin{tabular}{clccc}
\hline No & Nama Lokasi & Rencana (Ha) & $\begin{array}{c}\text { Realisasi } \\
(\mathrm{Ha})\end{array}$ & $\begin{array}{c}\text { Persentasi } \\
(\%)\end{array}$ \\
\hline 1 & Bendang & 4,71 & 4,86 & 101,18 \\
2 & North & 13,49 & 12,11 & 89,77 \\
3 & Pit 5 & 3,86 & 5,46 & 164,38 \\
4 & Panorama B-BX & 2,92 & 4,80 & 141,45 \\
\hline
\end{tabular}

Sumber : Dokumen RKTTL

\section{Penanaman Penutup Tanah (covercrop)}

Hasil pengamatan dilapangan menunjukkan, bahwa jenis covercrops yang digunakan adalah Pueraria javanica dan Calopogonium mucunoides (Permentan No. 141/Kpts/HK. 150/M/2/2019) dengan jumlah penggunaan sebesar $155 \mathrm{~kg}$ untuk kebutuhan lahan $10,26 \mathrm{Ha}$.

\section{Penanaman Tanaman Pionir}

Berdasarkan pemantauan dilapangan, bahwa jenis tanaman pionir yang ditanam di area pasca tambang terdiri dari: Trembesi, Johar, Nangka, Mangga, Durian, dan Karet (tabel 5) (Permentan No. 141/Kpts/HK. 150/M/2/2019). 
Tabel 5. Penanaman Tanaman Pionir

\begin{tabular}{|c|c|c|c|}
\hline Tahun & Lokasi Penanaman & Jenis Tanaman & $\begin{array}{l}\text { Jumlah } \\
\text { (Pohon) }\end{array}$ \\
\hline & Pit 30 & Trembesi & 200 \\
\hline & & Johar & 280 \\
\hline & & Nangka & 200 \\
\hline & & Mangga & 20 \\
\hline & Panorama Utara & Trembesi & 200 \\
\hline & & Johar & 240 \\
\hline & & Nangka & 160 \\
\hline & & Mangga & 80 \\
\hline & & Nangka & 120 \\
\hline & Pit GL 5 & Salam & 80 \\
\hline \multirow{21}{*}{2016} & & Mangga & 40 \\
\hline & & Durian & 40 \\
\hline & & Karet & 1,200 \\
\hline & Pit Pinang 1 A2-A3 & Trembesi & 200 \\
\hline & & Johar & 200 \\
\hline & & Mangga & 20 \\
\hline & & Trembesi & 200 \\
\hline & Pit Pinang Ph 1 A2-A3 & Johar & 200 \\
\hline & & Mangga & 10 \\
\hline & & Trembesi & 120 \\
\hline & GL 4 Disp.Senong & Mangga & 5 \\
\hline & & Durian & 5 \\
\hline & & Nangka & 120 \\
\hline & & Mangga & 10 \\
\hline & GL 5 & Durian & 10 \\
\hline & & Salam & 80 \\
\hline & & Trembesi & 200 \\
\hline & GL 7 & Johar & 200 \\
\hline & & Mangga & 10 \\
\hline & & Durian & 10 \\
\hline & & Trembesi & 80 \\
\hline \multirow[t]{17}{*}{2017} & TDSE Ph 5 C2 & Johar & 200 \\
\hline & & Mangga & 5 \\
\hline & & Durian & 5 \\
\hline & Pit 30 & Nangka & 200 \\
\hline & & Trembesi & 200 \\
\hline & & Johar & 280 \\
\hline & & Mangga & 20 \\
\hline & GL 5/6 A16_Tik.Kopta & Rambai & 57 \\
\hline & & Nangka & 120 \\
\hline & & Trembesi & 120 \\
\hline & & Mangga & 13 \\
\hline & Panorama Utara & Nangka & 80 \\
\hline & & Trembesi & 80 \\
\hline & & Johar & 120 \\
\hline & & Mangga & 40 \\
\hline & GL 7 A7-A8 & Mangga & 120 \\
\hline & Jumlah & & 2.920 \\
\hline
\end{tabular}

Sumber : Dokumen Rencana Reklamasi

Metode penanaman tanaman pionir tersebut dengan membuat lubang tanam ukuran $40 \mathrm{~cm}$ x $40 \mathrm{~cm}$ $\mathrm{x} 40 \mathrm{~cm}$. Selanjutnya lubang tersebut diisi dengan top soil yang bercampur pupuk kompos dan dolomit (Paul T. Behum, et al, 2018). Kebutuhan kompos sebanyak 1-1,5 kg per-lubang agar dapat memuat lebih banyak media tanam yang subur untuk pertumbuhan tanaman pionir (Layanan Informasi Desa, 2020) atau 2,2 - 6,2 ton per-ha (hasil uji laboratorium kesuburan tanah) untuk mencapai kandungan organik dan Nitrogen di dalam tanah pada tingkat yang sedang.

\section{Revegetasi}

Vegetasi dianggap menjadi perlindungan lereng dan pengendalian erosi (Vibhash Ranjan, et al, 2015). Upaya untuk mengatasi erosi dan degradasi lahan bergantung pada kegiatan reklamasi (Phillips et al. 2013). Berdasarkan hasil analisis, bahwa pelaksanaan revegetasi hanya mencapai $78,13 \%$ (tabel 6 ) 
Tabel 6. Rencana dan Realisasi Pelaksanaan Revegetasi

\begin{tabular}{cllcccc}
\hline No & Lahan & 2015 & 2016 & 2017 & Total \\
\hline 5 & Revegetasi Lahan & Rencana (Ha) & 60.33 & 42.72 & 62.12 & 165,17 \\
& & Realisasi (Ha) & 93.87 & 24.92 & 10.26 & 129,05 \\
& & Persentase (\%) & 155.59 & 58,33 & 16,52 & 78,13 \\
\hline
\end{tabular}

Sumber : Hasil analisis

Tabel 7. Kegiatan Revegtasi

\begin{tabular}{clcccc}
\hline No & Kegiatan & Unit & Rencana & Realisasi & Persentasi (\%) \\
\hline 1 & Penanaman & Pohon & 38.825 & 6.413 & 16,52 \\
2 & Tanaman Pokok & Pohon & 15.391 & 2.920 & 18,97 \\
3 & Penyulaman (Fast Growing) & Pohon & 12.135 & 4.700 & 38,73 \\
4 & Penyulaman (tanaman lokal) & Pohon & 4.221 & 1.000 & 23,69 \\
\hline
\end{tabular}

Sumber : Dokumen Rencana Reklamasi

\section{Pemeliharaan Vegetasi}

Pemeliharaan bertujuan untuk menjaga tanaman supaya tumbuh baik dan sehat serta tidak mengalami gangguan atau kerusakan baik yang disebabkan oleh kegiatan manusia ataupun sebagai akibat dari kegiatan hama dan penyakit yang dapat menyerang tanaman (Oktorina, S., 2017). Hasil evaluasi menunjukkan, bahwa kegiatan pelaksanaan penyiangan rumput hanya mencapai $71,45 \%$, Penyemprotan herbisida 10,50\%, Pemupukan 42,50\%, dan perawatan $59,73 \%$ (tabel 8).

Tabel 8. Pemeliharaan Revegetasi

\begin{tabular}{clcccc}
\hline No & \multicolumn{1}{c}{ Kegiatan } & Unit & Rencana & Realisasi & Persentasi (\%) \\
\hline 1 & Penyiangan rumput & Ha & 480 & 343 & 71,46 \\
2 & Penyemperotan Herbisida & Liter & 800 & 84 & 10,50 \\
3 & Pemupukan & Kg & 14.000 & 5.950 & 42,50 \\
4 & Perawatan/Pemeliharaan & Pohon & 77.398 & 46.233 & 59,73 \\
\hline
\end{tabular}

Sumber: Dokumen RKTTL

\section{Kendala Reklamasi}

Penurunan kualitas tanah lapisan atas (top soil) pada lahan bekas tambang ditandai dengan rusaknya struktur tanah, erosi dipercepat, pencucian yang berlebihan, pemadatan tanah, penurunan $\mathrm{pH}$ tanah, akumulasi logam berat dalam tanah, penipisan bahan organik, penurunan hara tanaman, penurunan kapasitas tukar kation, penurunan aktivitas mikroba (Mensah, A.K. 2015). Hasil pengamatan lapangan menunjukkan, bahwa kendala pelaksanaan reklamasi, adalah penebaran top soil kurang merata, kemiringan permukaan lahan tidak sesuai SOP yaitu 2-4\% (Permenhut No. P. 4/Menhut-II/2011, dan Permen ESDM No. 07 Tahun 2014). Selain dari itu $\mathrm{pH}$ tanah $(3,68)$ dan C-organik $(1,47 \%)$, dan $\mathrm{N}$ Total $(0,12 \%$, Tabel 9).
Tabel 9. Hasil Uji Kualitas Tanah

\begin{tabular}{llc}
\hline No & Unsur & Hasil Uji \\
\hline 1 & $\mathrm{pH}$ & 3,68 \\
2 & C-Organik (\%) & 1,47 \\
3 & N Total (\%) & 0,12 \\
\hline
\end{tabular}

\section{Keberhasilan Reklamasi dan Revegetasi}

Berdasarkan hasil analisis, menunjukkan bahwa tingkat keberhasilan kegiatan reklamasi dan revegetasi di area pasca tambang PT. Bukit Baiduri Energi sebesar (Tabel 10):

$$
T N=\frac{40}{51} \times 100 \%=78,43 \%
$$


Tabel 10. Hasil Evaluasi Keberhasilan

\begin{tabular}{|c|c|c|c|c|}
\hline No. & Kegiatan & Standar Keberhasilan & Nilai & Hasil Evaluasi \\
\hline \multirow[t]{9}{*}{1} & Penatagunaan Lahan & & & \\
\hline & a. Penataan Permukaan tanah & $\begin{array}{l}\text { Lahan ditata }<60 \% \text { dari } \\
\text { rencana }\end{array}$ & 1 & \\
\hline & & Stabilitas Timbunan & 3 & Tidak longsor \\
\hline & $\begin{array}{l}\text { b. Penimbunan kembali lahan bekas } \\
\text { tambang/ Backfilling }\end{array}$ & $\begin{array}{l}\text { Pengisian kembali LBT } 60 \% \text { - } \\
80 \%\end{array}$ & 2 & $62.00 \%$ \\
\hline & & Stabilitas Timbunan & 3 & Tidak longsor \\
\hline & $\begin{array}{l}\text { c. Penebaran tanah tanah zona } \\
\text { pengakaran }\end{array}$ & $\begin{array}{l}\text { Lebih } 75 \% \text { dari total areal } \\
\text { bekas tambang }\end{array}$ & 3 & $151.33 \%$ \\
\hline & d. $\mathrm{pH}$ tanah & Buruk $(<4.5)$ & 1 & 3.68 \\
\hline & $\begin{array}{l}\text { e. Pengendali-an Erosi dan } \\
\text { Pengelolaan Air }\end{array}$ & $\begin{array}{l}\text { Terjadi erosi parit dan tidak } \\
\text { terjadi sedimentasi }\end{array}$ & 2 & Tidak terjadi sedimentasi \\
\hline & & $\begin{array}{l}\text { Panjang drainase sesuai } \\
\text { rencana awal }\end{array}$ & 3 & sesuai rencana awal \\
\hline \multirow[t]{6}{*}{$2 c$} & Revegetasi & & & \\
\hline & a. Penanaman & $\begin{array}{l}\text { 10,26 Ha dari rencana } 62,12 \\
\mathrm{Ha}\end{array}$ & 1 & $16.52 \%$ \\
\hline & a. Pertumbuhan Tanaman & $85 \%$ & 3 & Baik \\
\hline & $\begin{array}{l}\text { c. Pengelolaan material pembangkit } \\
\text { AAT }\end{array}$ & $\begin{array}{l}\text { Material pembangkit AAT }> \\
80 \% \text { diisolasi }\end{array}$ & 3 & Sesuai rencana \\
\hline & & Bangunan Pengendali & 3 & Alur Erosi ringan \\
\hline & & Sedimen pond & 3 & BMLpH 6-7 \\
\hline \multirow[t]{5}{*}{3} & Penyelesaian Akhir & & & \\
\hline & a. Penutupan Tajuk & $\begin{array}{l}\text { Penutupan tajuk }>80 \% \text { sesuai } \\
\text { rencana }\end{array}$ & 3 & $90 \%$ dari rencana \\
\hline & b. Pemeliharaan & Pemupukan $>80 \%$ & 3 & $90 \%$ \\
\hline & & $\begin{array}{l}\text { Pengendalian Gulma, Hama, } \\
\text { Penyakit }\end{array}$ & 2 & Kurang \\
\hline & & $\begin{array}{l}\text { Penyulaman } \\
(<60 \% \text { tanaman mati })\end{array}$ & 1 & $<60 \%$ \\
\hline 4 & Keberhasilan & $\begin{array}{l}\text { Sedang } 60-80 \% \text { dari tingkat } \\
\text { keberhasilan }\end{array}$ & & $78,43 \%$ \\
\hline
\end{tabular}

Sumber : Hasil Analisis

\section{PEMBAHASAN}

Penimbunan kembali lahan bekas tambang harus mengikuti pemindahan batubara serentak berdasarkan kondisi penambangan. Harus sesuai jadwal yang diusulkan dengan analisis pendukung (Wyoming, 2017). Hasil wawancara Health Safety and Environtment (HSE), menyebutkan bahwa "reklamasi tahun 2017 tidak tercapai disebabkan penambangan Pit Merandai CD2 dan blok North tidak sesuai dengan jadwal yang telah ditentukan karena keterlambatn kontraktor". Berdasarkan rencana dan realisasi pelaksanaan reklamasi (tabel 2) menunjukkan, bahwa reklamasi hanya mencapai $16,52 \%$ atau terealisasi 10,62 Ha dari target 62,12 Ha. Sesuai peraturan Pemerintah Republik Indonesia (Permen ESDM No. 07 Tahun 2014), menyebutkan bahwa presentasi sebesar $16,52 \%$ dikategorikan pelaksanaan reklamasi buruk $(<60 \%)$. Untuk mencapai sistem ikatan reklamasi yang berhasil, beberapa faktor penting yang diperhatikan adalah (a) undang-undang dan peraturan (b) otoritas administratif (c) jenis obligasi (d) ukuran obligasi (e) metode perhitungan (f) pelepasan obligasi dan (g) partisipasi publik (Linlin Cheng \& Jeffrey G. Skousen, 2017).

\section{Evaluasi Kegiatan Revegetasi}

Revegetasi adalah usaha untuk memperbaiki dan memulihkan vegetasi yang rusak melalui kegiatan penanaman dan pemeliharaan pada lahan bekas penggunaan kawasan hutan (Permenhut Nomor 60 Tahun 2009). Vegetasi harus beradaptasi dengan lingkungan alam, dan menyesuaikan diri dengan kebiasaan vegetasi dan spesiesnya yang disesuaikan dengan fisiologis dan ekologis. Cara ini dapat dikelola dengan mudah dengan investasi rendah, dan memberi imbalan banyak. Ini sesuai dengan hukum suksesi alami tanaman, dan bermanfaat bagi stabilitas dan kelanjutan pengembangan vegetasi (Y.Wang \& H.T. $\mathrm{Yu}$, 2015). Spesies tanaman yang dipilih harus memiliki kemampuan toleransi yang kuat seperti tahan kekeringan, tahan asam, tahan kekeringan, ketahanan kemiringan, ketahanan logam berat, dan tumbuh dengan cepat, mudah ditanam, dan tingkat kelangsungan hidup yang tinggi (Y.B. Zhu, L.B. et al, 2015). Berdasarkan hasil evaluasi, bahwa kegiatan revegetasi hingga tahun 2017 terealisasi mencapai 
$78,13 \%$ (tabel 6). Dengan mengacu pada standar keberhasilan, bahwa apabila realiasasi pelaksanaan revegetasi tidak mencapai $60 \%(<60 \%)$, maka tingkat keberhasilan termasuk kategori buruk (Permen ESDM No. 07 Tahun 2014). Berhasil tidaknya revegetasi dipengaruhi oleh berbagai faktor seperti (1) Penataan lansekap, (2) aspek kesuburan pada media tanam, dan (3) pemilihan tanaman untuk revegetasi tambang (Antares Multi Energi, 2019).

\section{Tingkat Keberhasilan Reklamasi dan Revegetasi}

Reklamasi yang berhasil, sebagaimana diperlukan untuk memenuhi tuntutan masyarakat saat ini, membutuhkan rekayasa, desain, dan rekonstruksi, bukan hanya permukaannya, dan kendali atas air yang meninggalkan lokasi tambang (Jeff Skousen, Carl E. Zipper, 2014).

Kepadatan tanah merupakan salah satu faktor pembatas bagi pertumbuhan tanaman pada lahan bekas tambang. Hal ini karena kebanyakan vegetasi tidak mampu memperpanjang akar efektif karena berat jenis yang tinggi pada lahan bekas tambang batubara (Sheoran et al.2010). Ketebalan penebaran top soil kurang merata, karena sebagian lahan ditebar mengikuti kontur permukaan lahan yang belum rata. Untuk mengatasi hal tersebut, perlu mengupayakan permukaan lahan diratakan terlebih dahulu sebelum top soil ditebar, diusahakan ketebalan top soil yang ditebar lebih dari $30 \mathrm{~cm}$ sesuai rencana.

Dari hasil uji kualitas tanah, menunjukkan bahwa $\mathrm{pH}$ tanah sangat asam dan C-organik dan $\mathrm{N}$ Total sangat rendah mengakibatkan tanah tidak subur dan vegetasi sangat sulit untuk tumbuh (Uquetan U. I. at al, 2017). Berdasarkan hasil evaluasi, bahwa keberhasilan pelaksanaan reklamasi dan revegetasi hanya mencapai 78,43\%, dimana standarisasi pelaksanaan reklamasi pada pada $60 \%$ - $80 \%$ termasuk kategi sedang.

\section{Optimalisasi Pelaksanaan Reklamasi dan Revegetasi} Reklamasi lahan harus didorong untuk direncanakan sebelum kegiatan penambangan dan perlu dirancang rencana reklamasi terlebih dahulu yang harus dinamis dengan penambangan batubara. Undang-undang dan peraturan harus mudah diimplementasikan, serta harus menggunakan dana reklamasi untuk meningkatkan kelayakan dan relevansi reklamasi (J.L. Gao \& X.Y. Xu, 2015). Dan pembentukan metode reklamasi lahan pertambangan yang rusak terkait erat dengan faktor-faktor daerah seperti iklim, hidrologi, bentuk lahan, metode penambangan, dan bentuk perusakan lahan (Y.Q. Pan, et al. 2015). Sesuai dengan kondisi sumber daya lingkungan dari iklim, tanah dan hidrologi di daerah pertambangan, perlu untuk mengambil tindakan rekayasa dan tindakan menanam dikombinasikan dan mengembangkan rekonstruksi ekologis sesuai dengan ukurannya dengan kondisi local (Wang \& Shang, 2015). Kegiatan reklamasi perlu kolaborasi pemerintah dan perusahaan, Pemerintah harus membangun kebijakan perlindungan lingkungan yang sesuai dan perencanaan jangka panjang, memainkan peran membimbing dan berinvestasi dalam pekerjaan perlindungan dasar lingkungan, sedangkan perusahaan tambang menetapkan konsep bahwa manfaat lingkungan harus menjadi bagian dari manfaat perusahaan, memperhatikan perlindungan lingkungan dari tahap desain dan konstruksi dalam pengembangan dengan perlindungan lingkungan secara bersamaan (Liu, et al, 2015). Dengan harapan area pasca tambang yang telah direklamasi dapat membantu mengatur iklim lokal, mereka dapat digunakan untuk produksi bahan baku dan bioenergi, untuk rekreasi atau untuk mendorong keanekaragaman hayati (Peter Wirth, et al., 2018).

\section{SIMPULAN}

Berdasarkan uraian hasil dan pembahasan, maka disimpulkan Target area reklamasi tahun 20152017 seluas 197,24 Ha, sedangkan yang terealisasi $190,06 \mathrm{Ha}$ atau 55,29\%, sementara yang telah dilakukan revegetasi seluas 129,05 $\mathrm{Ha}$ atau 118,33\%. Tingkat keberhasilan reklamasi dan revegetasi mencapai $74,43 \%$ atau termasuk kategori sedang $(60 \%$ - 80\%). Kualitas tanah yang rendah, yaitu $\mathrm{pH}$ tanah $(3,68)$, C-organik $(1,47 \%)$, dan $\mathrm{N}$ Total $(0,12 \%)$ menyebabkan tanah tidak subur dan vegetasi sulit tumbuh,

\section{UCAPAN TERIMA KASIH}

Ucapan terima kasih penulis ucapkan kepada pihak-pihak yang telah membantu dalam terlaksananya penelitian ini.

\section{DAFTAR PUSTAKA}

Dokumen AMDAL Kegiatan Pertambangan Batubara. (2004). PT. Bukit Baiduri Energi, Samarinda.

Dokumen Rencana Reklamasi. (2011-2015). Kegiatan Pertambangan Batubara PT. Bukit Baiduri Energi, Samarinda.

Dokumen Rencana Reklamasi Tahun. (2016-2020). Kegiatan Pertambangan Batubara PT. Bukit Baiduri Energi, Samarinda

Dokumen Rencana Kerja Tahunan Teknik dan Lingkungan. (2018). Kegiatan Pertambangan Batubara PT. Bukit Baiduri Energi, Samarinda.

F.D. Liu, X.Z. Xu, C.B. Zhao \& C.X. Ji. (2015). A case study of land reclamation and ecological restoration of mine. Legislation, Technology and Practice of Mine Land Reclamation Taylor \& Francis Group, London, ISBN978-1-138-02724-4 http://93.174.95.29/main/268F0D3D22DA38B70 B13DC5D0C623E50

Febriarlita, L. (2017). Tanah (soil)https://luciafebriarlita17.wordpress.com/2014 /01/23/tanah-soil/. Retrieved 2020-05-14

Festin., Tigabu, E.S., Chileshe, M., Syampungani, M.N., \& Stephen. (2018). Progresses in restoration of post-mining landscape in Africa. Journal For. Res. (2019) 30(2):381-396. https://doi.org/10.1007/s11676-018-0621-X 
Gao, J.L., \& Xu, X.Y. (2015). Analysis and countermeasures of coal mining impact on agriculture production from the micro perspective. Legislation, Technology and Practice of Mine Land Reclamation Taylor \& Francis. Group, London, ISBN 978-1-138-02724-4

http://93.174.95.29/main/268F0D3D22DA38B70 B13DC5D0C623E50.

Jeff Skousen., \& Carl E. Zipper, (2014). Post-mining policies and practices in the Eastern USA coal region Int Journal Coal Sci Technol (2014) 1(2):135-151, https://doi.org/10.1007/s40789-014-0021-6

Multi Energi, (2019). Pemilihan Tanaman untuk RevegetasiTambang.http://www.antaresenergi.co $\mathrm{m} /$ pemilihan-tanaman-untuk-revegetasi tambang/. Retrieved 2020-05-15. ArcGIS for Home Use Program. Retrieved 2020-05-11.

Laporan Pelaksanaan Jaminan Reklamasi Tahun. (2011-2016). Kegiatan Pertambangan Batubara PT. Bukit Baiduri Energi, Samarinda.

Layanan Informasi Desa, (2020). Cara Mengaplikasikan Pupuk Kandang pada Tanaman Budi Daya. Retrieved 2020-05-13 https://8villages.com/full/petani/article/id/5e719 7f7619ead2e4f5f3a1f

Linlin, C., \& Jeffrey, G. (2017) Comparison of international mine reclamation bonding systems with recommendations for China. Int $\mathrm{J}$ Coal Sci Technol (2017) 4(2):67-79. https://doi.org/10.1007/s40789-017-0164-3

Mensah, A.K. (2015). Role of revegetation in restoring fertility of degraded mined soils in Ghana: A review, Int. J. Biodivers. Conserv. Vol. 7 (2): 57-80. http://dx.doi.org/10.5897/IJBC2014.0775

Paul, T. B., Yoginder, P., Chugh, L.L. (2018). Management of coal processing wastes : studies on an alternate technology for control of sulfate and chloride discharge Int $\mathrm{J}$ Coal Sci Technol (2018)5(1):54-63, https://doi.org/10.1007/s40789. 017-0185-y

Peraturan Menteri Energi dan Sumberdaya Mineral Nomor 07 Tahun 2014 tentang Pelaksanaan Reklamasi dan Pascatambang pada Kegiatan Usaha Pertambangan Mineral dan Batubara.

Permentan No. 141/Kpts/HK.150/M/2/2019 Tentang Jenis Komoditas Tanaman

Peraturan Menteri Energi dan Sumberdaya Mineral Nomor 1827 K/30/MEM/2018 Tahun 2018 tentang Kaidah Teknik Pertambangan yang Baik

Permenhut N. P.4/Menhut-II/2011. Tentang Pedoman Reklamasi Hutan.

Peter Wirth, Jiang Chang, Ralf-Uwe Syrbe, Wolfgang Wende \& Tinghao Hu. (2018). Green infrastructure: a planning concept for the urban transformation of former coal-mining cities. Int $\mathrm{J}$ Coal Sci Technol (2018) 5(1):78-91. Published online: 24 April 2018. https://doi.org/10.1007/s40789-018-0200-y

Phillips. (2013). Revegetation of steeplands in France and New Zealand: geomorphic and policy responses. New Zealand Journal of Forestry Science.

http://www.nzjforestryscience.com/content/43/1 $/ 14$

Rum Jungle. (2016). Main Pit Backfilling Concept Approaches, Robertson GeoConsultants Inc. Departement of Mines and Energy. RGC Report $183006 / 3$

Silverman, D. (2015). Interpreting Qualitative Data. SAGE Publications Inc. 2445 Teller Road Thousand Oaks, California 91320

Sarita Oktorina. (2017). Kebijakan Reklamasi dan Revegetasi Lahan Bekas Tambang. Al Ard : Jurnal Teknik Lingkungan Vol. 3 No.1 UIN Sunan Ampel Surabaya. e-ISSN: 2549-1652. www.alard.uinsby.ac.id

Uquetan U. I. (2017). Evaluation of Soil Quality in Relation to Landuse Effect in Akamkpa, Cross River State - Nigeria. Applied Ecology and Environmental Sciences. 5(2), Published online: August 05, 2017. 35-42.

http://doi.org/10.12691/aees-5-2-2

Vibhash Ranjan, Phalguni Sen, Dheeraj Kumar and Arjun Sarsawat. (2015). A review on dump slope stabilization by revegetation with reference to indigenous plant. Ecological Processes is affiliated with the Institute of Applied Ecology, Chinese Academy of Sciences. https://doi.org/10.1186/s13717-015-0041-1

Wang, D.C., \& Shang, Z. (2015). Research on the mine afforesting reclamation technology of waste dump in Shengli 1 Opencast Coal Mine site. Legislation, Technology and Practice of Mine Land Reclamation Taylor \& Francis Group, London, ISBN 978-1-138-02724-4

http://93.174.95.29/main/268F0D3D22DA38B70 B13DC5D0C623E50

Wyoming State Rules and Regulations, (2017). Environmental Quality, Department of Land Quality-Coal. Accessed 24th Jan 2017

http://deq.wyoming.gov/lqd/resources/ guidelines/. Retrieved 2020-05-13

Wyoming Department of Environmental Quality, (2017). Land quality division: guidelines. http://deq.wyoming.gov/lqd/resources/ guidelines/. Retrieved 2020-05-14

Yinli Bi , Yanxu Zhang, Hui Zou. (2018). Plant growth and their root development after inoculation of arbuscular mycorrhizal fungi in coal mine subsided areas. Int J Coal Sci Technol (2018) 5(1):47-53. https://doi.org/10.1007/s40789-018-0201-X

Y. Wang \& H.T. Yu. (2015). The revegetation of south dump in Yuanbaoshan open pit coal mine. Technology and Practice of Mine Land Reclamation. Taylor \& Francis Group, London, ISBN 978-1-138-02724-4 http://93.174.95.29/main/268F0D3D22DA38B70 B13DC5D0C623E50

Y.B. Zhu, L.B. (2015). Study on assessment system of rehabilitation on acid mine waste rock dump. Technology and Practice of Mine Land 
Reclamation. Taylor \& Francis Group, London, ISBN 978-1-138-02724-4.

http://93.174.95.29/main/268F0D3D22DA38B70 B13DC5D0C623E50

Y.Q. Pan. (2015). Study on reclamation modes of coal mining damaged land in Henan Province. Legislation, Technology and Practice of Mine Land Reclamation. Taylor \& Francis Group, London, ISBN 978-1-138-02724-4.

http://93.174.95.29/main/268F0D3D22DA38B70 B13DC5D0C623E50
Zhenqi, Hu. (2018). Special issue on land reclamation in ecological fragile areas. International Journal of Coal Science \& Technology (2018) 5(1):1-2. https://doi.org/10.1007/s40789-018-0206-5

Zhaopeng, Zhang , Zengyuan Li, Xin Tian. (2018). Vegetation change detection research of Dunhuang city based on GF-1 data. Int. Journal Coal Sci Technol (2018) 5(1):105-111

https://doi.org/10.1007/s40789-018-0195-4 